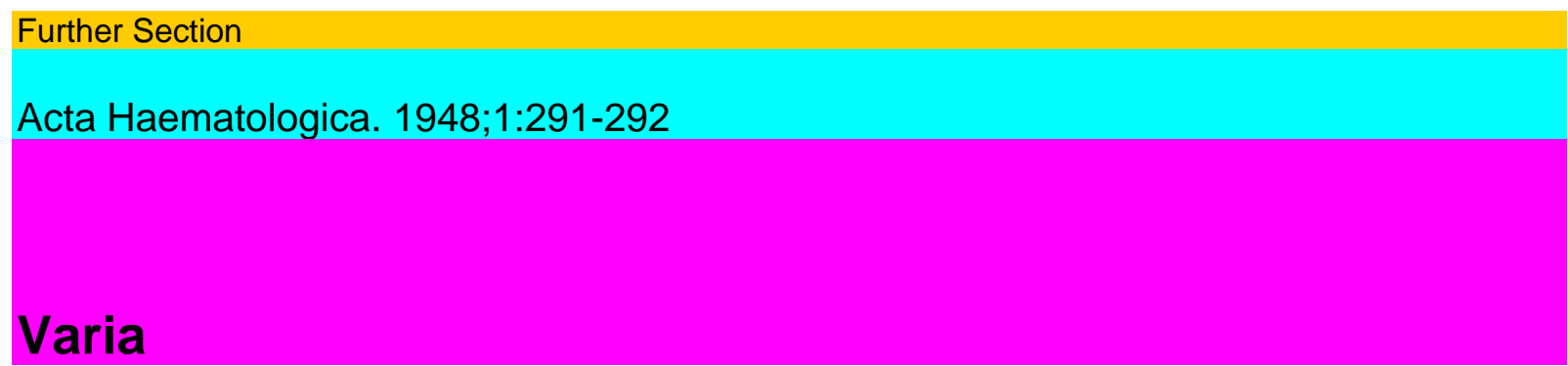

Blood Group News. P. H. Andresen M. D. Chief of serological Departement of

University Institute of legal Medicine, Copenhagen. Association for mutual

Information. 1948 August. Letter of Invitation.

During the past years the research of blood groups has developed to a very great extent, and on account of their applicability and importance in various fields treatises are published in a large number of different periodicals thus causing the individual research worker great difficulty in making himself acquainted with new development.

In order to relieve this difficulty I am proposing the establishment of an «Association For Mutual Information On Blood Groups» with the aim of bringing to the members information of any advance within this field.

All members must send to the association details of any new work when printed. In return he will receive a monthly list containing all collected information. Any active blood group research worker who is publishing works in this field of science may be admitted as member of the Association.

\title{
292 Varia
}

All actively engaded research workers are asked to join the Association. Please write to me under the address mentioned below at the same time sending me four international reply coupons. Your exact address should be type written. The procedure will be as follows: Any member pubishing an article forwards information to me as editor of the list «Blood Group News». The information is to be sent in by postcard of the size $7,5 \times 12,5 \mathrm{~cm}$ and should be type written as shown in fig. 1. (In order that this information may be published without undue expense it is of great importance that they are easily readable and correctly arranged.) If the title is not written in English, French oder German it should be accompanied by a translation into English. Only one article should be written on each card.

It will be of great importance to receive informations, not only, about recently published works, but also about works published since the beginning of 1948. For this purpose send in cards with information all about articles published during this year together with the application for membership. The Association will be of the greatest importance to all blood group research workers and I sincerely hope that you will be interested in joining the Association. Blood Group Research Workers who have promised to join the Association: R. T. Walsh, Sydney (Australia); P. Moreau, Liege (Belgium); E. Freies-leben, Copenhagen, Denmark; P. Marcussen, Copenhagen (Denmark); A. E. Mourant, London (England); R. R. Race, London (England); R. R. van Log-hem, Amsterdam (Holland); O. Hartmann, Oslo (Norway); B. Bromann, Stockholm (Sweden); B. Jönsson, Stockholm (Sweden); A. Lindau, Lund (Sweden); E. Wolff, Stockholm (Sweden); B. Rex-Kiss, Budapest (Hungary). «Blood Group News» will be delivered only on these conditions to active research workers but a certain number of copies will be distributed by Ejnar Munksgaard, Copenhagen, to libraries and others at a price at which it may be produced. 
It has not been possible to get the address of all Blood Group research Workers and the Editor will be glad to receive further names and addresses.

Wie uns Prof. Hernan Alessandri aus Santiago (Chile) berichtet, besteht dort seit 1945 eine Gesellschaft für Hämatologie und Transfusion (Sociedad de Hematologia y Transfusion), deren Präsident zurzeit Dr. Luis Sandoval Smart ist. Bisher haben Tagungen der Gesellschaft in Cordova (Argentinien) und Santiago stattgefunden unter Teilnahme zahlreicher Fachgenossen aus Brasilien, Peru, Uruguay und Chile. Das erste Heft einer hämatologischen Zeitschrift «Sangre» ist in Vorbereitung.

Zahlreiche hämatologische Themen wurden im Jahr 1947 in der Med. Gesellschaft von Santiago (Sociedad Médica de Santiago) behandelt. Die Ab-teilung für Hämatologie des Servicio A (Med. Abt. des Hospitals Del Salvador) veröffentlichte Mitteilungen über: Urethanbehandlung der chronischen Leuk-ämie, Erfahrungen über die Behandlung maligner Lymphome mit Senfgas, Therapie der macrocytischen Anämien mit Folsäure und kasuistische Beiträge über Familiäre Pseudohämophilie und Achrestische Anämie. Auf der 19. Jahres-versammlung der Med. Gesellschaft von Santiago berichtete die Hospitalabteilung über die Einteilung, Diagnose und Behandlung der Anämien auf Grund des Materials der letzten 10 Jahre.

Die Drüsenpunktion hat sich bei den verschiedensten Lymphdrüsenaffektio-nen in mehr als 1500 Fallen als ein sehr wertvolles Hilfsmittel mit etwa 85 \% diagnostisch verwertbaren Ergebnissen erwiesen. 